\title{
Dos Classics Illustrated à Edição Maravilhosa: Victor Hugo entre textos e paratextos (1949-1959) ${ }^{1}$
}

\section{From Classics Illustrated to Edição Maravilhosa: Victor Hugo among Texts and Paratexts (1949-1959)}

\author{
Dennys Silva-Reis (UnB) \\ Bárbara Guimarães Lucatelli (UnB)
}

Resumo: $\mathrm{O}$ presente artigo analisa quatro HQs inspiradas nos romances de Victor Hugo e suas respectivas traduções para o português: $O$ Corcunda de Notre Dame (1949) - The Hunchback of Notre Dame (1946), Os miseráveis (1951) - Les Miserables (1943), Os Trabalhadores do Mar (1952) - The Toilers of the Sea (1949), e O Homem que Ri (1952) - The Man Who Laughs (1950). Para tal empreendimento nos detemos na observação do texto traduzido e na comparação entre paratextos que acompanham a tradução e o texto fonte. Desta forma, mostramos que enquanto as HQs em inglês eram produzidas como motivação para leitura dos clássicos, os brasileiros tentavam alcançar o status de Literatura.

\footnotetext{
1 O presente trabalho foi apresentado no simpósio "Quadrinhos em tradução" do XI Congresso Internacional da ABRAPT e no V Congresso Internacional de Tradutores em 2013 em Florianópolis. Agradecemos as contribuições de todos os participantes deste simpósio, bem como a de Fernanda Conciani.

" Mestre em Estudos de Tradução (UnB) e doutorando em Literatura (UnB). Assina o blog Historiografia da Tradução no Brasil (http://historiografiadatraducaobr.blogspot.com.br). Email: reisdennys@gmail.com

"** Mestre em Estudos de Tradução (UnB). E-mail: blucatelli@gmail.com
} 
SILVA-ReIS, D.; LuCATELLI, B. G. - Dos Classics Illustrated à Edição Maravilhosa: Victor Hugo entre textos e paratextos (1949-1959)

Palavras-chaves: Edição Maravilhosa; Classic Illustrated; tradução de quadrinhos; história dos quadrinhos

Abstract: This article analyzes four comics inspired by the novels by Victor Hugo and their translations into Portuguese: O Corcunda de Notre Dame (1949) - The Hunchback of Notre Dame (1946), Os Miseráveis (1951) - Les Miserables (1943), Os Trabalhadores do Mar (1952) - The Toilers of the Sea (1949), and O Homem que ri (1952) - The Man Who Laughs (1950). For this project, we focused on analyzing the translated texts and comparing paratexts, which are part of both the translation and the source texts. In this paper, we intend to show that while comics in English were produced as motivation for reading the classics, Brazilian translations tried to reach the Literature status.

Keywords: Edição Maravilhosa; Classics Illustrated; translation of comics; history of comics

\section{Introdução}

Sabe-se que o grande impulso da formação do mercado editorial dos quadrinhos brasileiros se deu com as publicações da Editora EBAL que, majoritariamente, eram importadas, traduzidas e postas à venda. Dentre esses quadrinhos, estavam os primeiros romances gráficos conhecidos e vendidos no Brasil e que também eram parte da Edição Maravilhosa.

Embora a Edição Maravilhosa tenha sido composta também de traduções intersemióticas nacionais - adaptações de romances brasileiros à linguagem dos quadrinhos - nos ocuparemos, neste artigo, apenas das traduções interlinguais a fim de delimitar a pesquisa ao campo da adaptação e do processo de tradução de quadrinhos já elaborados no estrangeiro e retrabalhados para o público brasileiro entre a década de 1949 e 1959. 
SILVA-REIS, D.; LuCATELLI, B. G. - Dos Classics Illustrated à Edição Maravilhosa: Victor Hugo entre textos e paratextos (1949-1959)

Com os limites de espaço do presente artigo, elegemos tão somente quatro HQs da primeira série da Edição Maravilhosa no Brasil e seus respectivos HQs fonte da primeira série de Classics Illustrated nos Estados Unidos: O Corcunda de Notre Dame (1949) - The Hunchback of Notre Dame (1946), Os miseráveis (1951) - Les Miserables (1943), Os Trabalhadores do Mar (1952) - The Toilers of the Sea (1949), e O Homem que Ri (1952) - The Man Who Laughs (1950). A escolha se fez pela simples razão de que Victor Hugo, à época, era considerado um dos clássicos mais lidos e difundidos universalmente e que, para os eruditos, ler literatura francesa, seja no formato romance ou em outra mídia, era um modismo de sucesso comercial e cultural.

Para além da análise do texto quadrinístico, exploramos também os paratextos do corpus estudado que nos transmitiram informações importantes a respeito da publicação de cada $\mathrm{HQ}$, bem como uma reconstituição dos contextos de publicação americano e brasileiro.

\section{De Comics Illustrated a Classics Illustrated}

A coleção Classic Comics foi criada em 1941 pelo russo Albert Lewis Kanter e o título de lançamento foi The Three Musketeers. A edição foi lançada nos chamados anos dourados das histórias em quadrinhos (1941) com o objetivo de conquistar leitores de Action Comics, Detective Comics e Marvel Comics para o formato proposto por ele, baseado em obras de Alexandre Dumas, Walter Scott, James Cooper, Herman Melville e Charles Dickens.

Com o progresso da publicação, a essência se afastou das histórias em quadrinhos e se aproximou dos livros ilustrados. Além disso, devido à Segunda Guerra Mundial, adultos que aprovavam a publicação e jovens que eram fãs começaram a enviar cartas para Albert Kanter pedindo que ele tentasse 
SILVA-ReIS, D.; LuCATELLI, B. G. - Dos Classics Illustrated à Edição Maravilhosa: Victor Hugo entre textos e paratextos (1949-1959)

afastar o estigma de "comics" de sua publicação. Isso porque, com a Guerra, havia restrição quanto ao uso do papel e, embora Kanter conseguisse comprar papel de outros editores de Nova lorque, a quantidade disponível não era suficiente para manter o tamanho padrão da Classic Comics, por isso foi necessário fazer uma redução no número de páginas.

Assim, em 1947, o nome da série mudou para Classics Illustrated e o primeiro título publicado sob o novo nome foi The Last Days of Pompeii. Ao mesmo tempo, na contracapa da edição $n^{\circ} 33$, The Adventures of Sherlock Holmes, foi impressa uma nota aos leitores, comunicando sobre a mudança do nome:

(...) The name of Classic Comics is being changed. Starting in March, with issue number 35, the new name will be 'Classics Illustrated'

Why the change? Well, ever since our first issues, you have said that they really aren 't 'comics'. We agree with you and so we're changing the name to 'Classics Illustrated'. ' (JONES 2011: 91).

Essa mudança de foco, entretanto, levou a uma crise, pois a publicação sofreu críticas severas de educadores, que alegavam que as publicações ainda eram histórias em quadrinhos como as outras e trivializavam as obras originais e, por isso, eram ainda piores.

Embora esse ponto de vista ainda seja compartilhado, é importante ressaltar que o objetivo da Classics Illustrated, desde o início, não foi substituir as obras clássicas, mas tornar o acesso a elas mais simples e imediato e ainda despertar o interesse dos jovens pelos títulos originais. 0 próprio Albert Lewis Kanter deixa seu objetivo claro na carta de lançamento: “Não é a nossa intenção substituir os antigos clássicos com as edições da

2 “(...) 0 nome da Classic Comics será trocado. A partir de março, com a edição número 35, o novo nome será Classics Illustrated. Por que a mudança? Ora, desde as nossas primeiras edições, vocês têm dito que não são exatamente 'comics'. Nós concordamos com vocês e, por isso, estamos mudando o nome para Classics Illustrated" (tradução nossa).

TradTerm, São Paulo, v. 27, Setembro/2016, pp. 247-277 www.usp.br/tradterm http://www.revistas.usp.br/tradterm/index 
SILVA-ReIS, D.; LUCATELLI, B. G. - Dos Classics Illustrated à Edição Maravilhosa: Victor Hugo entre textos e paratextos (1949-1959)

CLASSIC COMICS, mas sim despertar o interesse por essas obras-primas, assim como o desejo de ler o texto original" (JONES 2011: 12) ${ }^{3}$.

Inicialmente, mal compreendida pelos admiradores e estudiosos de HQs, a coleção Classics Illustrated conseguiu aos poucos ser vista como algo positivo para a cultura popular. 0 fato de ser diferente de tudo o que vinha sendo publicado causava estranheza e, por isso, certa rejeição. Basicamente, por não trazer super-heróis em suas páginas, as HQs da coleção pareciam não se encaixar nos padrões da época.

Entretanto, a ausência dos super-heróis foi exatamente o que a tornou especial e, depois, bem-sucedida. A coleção trazia em suas páginas adaptações de grandes clássicos mundiais, levando-os a um novo público dentro dos Estados Unidos e, então, a outros países, quando traduzidas. No Brasil, por exemplo, a Classics Illustrated chegou em 1948, quando a série Edição Maravilhosa publicou a edição de Os três Mosqueteiros em português (JONES 2001).

Ao longo de sua história, a Classics Illustrated não mediu esforços para inovar e conquistar o público. Desde o início, a publicação investiu bastante para que as capas fossem inovadoras e contratou artistas e ilustradores conhecidos para que os desenhos surpreendessem. Além disso, em 1951 começou a ser publicada a Classics Illustrated Junior, cujo público-alvo eram as crianças que se interessavam pelas histórias simplesmente porque gostavam dos enredos ou porque queriam ler versões simples e curtas dos clássicos que estudavam na escola.

Desde o começo, houve várias publicações de grandes clássicos até o início dos anos 1970, quando começaram a encontrar dificuldades de distribuição e, por isso, se interrompeu a produção. Aqui, vale ressaltar que a

\footnotetext{
3 "It is not our intent to replace the old established classics with these editions of the 'CLASSIC COMICS LIBRARY', but rather we aim to create an active interest in those great masterpieces and to instill a desire to read the original text" (JONES 2011: 12) (tradução nossa).
} 
SILVA-ReIS, D.; LuCATELLI, B. G. - Dos Classics Illustrated à Edição Maravilhosa: Victor Hugo entre textos e paratextos (1949-1959)

televisão ganhava cada vez mais espaço e, além disso, os custos para impressão também aumentaram, contribuindo para o fim da publicação.

\section{A Edição Maravilhosa da Editora Brasil-América Ltda (EBAL)}

A Editora Brasil-América Ltda. (EBAL) foi fundada por Adolfo Aizen em 1945 depois do fechamento do Suplemento Juvenil. Durante mais de trinta anos, foi uma das principais produtoras de quadrinhos da América do Sul. Além disso, foi responsável pela popularização dos principais super-heróis norte-americanos no Brasil e também a primeira responsável pela produção de quadrinhos feitos genuinamente por brasileiros. Inúmeros foram os títulos e as coleções publicadas pela editora e dentre elas está a Edição Maravilhosa (GOIDA; KLEINERT 2011).

A Edição Maravilhosa foi publicada durante os anos de 1950 e 1960 e transcrevia para a linguagem dos quadrinhos as obras mais conhecidas da literatura universal e nacional (VERGUEIRO 2011). Concretizando um projeto de Aizen de fornecer cultura e complemento educacional em quadrinhos, esta série surgiu como quadrinho educativo em linguagem atraente para as crianças, a fim de mostrar que esta linguagem/arte, além de entreter, também poderia ensinar e informar o público infantil (CIRNE et al. 2002).

As edições originais em inglês da Edição Maravilhosa eram produzidas nos Estados Unidos e publicadas nas séries Classics Illustrated e Classic Comics desde o começo da década de 1940. A primeira publicação no Brasil saiu em 1948 com o título Os três mosqueteiros, adaptação do livro homônimo de Alexandre Dumas. Os primeiros números circularam em formato menor, próximo ao do livro de bolso e, logo depois, cresceu para o formato chamado 
SILVA-ReIS, D.; LUCATELLI, B. G. - Dos Classics Illustrated à Edição Maravilhosa: Victor Hugo entre textos e paratextos (1949-1959)

de comic book ou formato americano (GONÇALO JUNIOR 2004). Nos primeiros 23 números, houve somente a publicação de autores estrangeiros, o que implicava diretamente a tradução das revistas americanas.

Esta série teve grande aceitação dos leitores e foi um dos grandes sucessos de publicação da editora EBAL. Todavia, recebeu várias críticas, dentre elas a de que a série era a responsável por tirar o interesse do leitor em ler a obra literária original. E, em um panfleto distribuído na porta das igrejas no interior de Minas Gerais pelo Departamento Nacional de Defesa da Fé e da Moral, a Edição Maravilhosa foi considerada como "desaconselhável para crianças" porque estava dentre as revistas de quadrinhos que "fomentavam o crime, o roubo e perturbavam a fantasia, etc." (GonçALO JUNIOR 2004). Além disso, os escritores contemporâneos à época discutiam sobre a legitimidade das versões simplificadas de livros e a eficiência da narrativa ilustrada.

Em 1954, devido aos vários debates e campanhas contra os quadrinhos no Brasil, a EBAL criou um regulamento editorial que deveria ser cumprido por todos (tradutores, redatores, artistas, etc.) tanto nas adaptações de histórias nacionais quanto estrangeiras. Eram 23 determinações nomeadas como "Os mandamentos das histórias em quadrinhos". Também houve a criação de um alerta editorial que estampava na capa das revistas em quadrinhos a faixa etária do público para quem eram dirigidas. A Edição Maravilhosa, por exemplo, era classificada como "para adultos". Além disso, ao final das quadrinizações da Edição Maravilhosa, Adolfo Aizen mandou colocar o seguinte lembrete:

As adaptações de romances ou obras clássicas para a EDIÇÃO MARAVILHOSA ou ALBUM GIGANTE são apenas um "aperitivo", um deleite para o leitor. Se você gostou dessa história, procure ler o próprio livro, adquirindo-o em qualquer livraria. E organize sua biblioteca - porque uma biblioteca é sinal de cultura e bom gosto. (ÁLBUM GIGANTE 1956: 48) 
SILVA-ReIS, D.; LUCATELLI, B. G. - Dos Classics Illustrated à Edição Maravilhosa: Victor Hugo entre textos e paratextos (1949-1959)

Dos 251 números publicados até 1961 da Edição Maravilhosa, 54 trouxeram obras brasileiras. Muitas das edições brasileiras deixavam a desejar por causa de alguns equívocos na transposição do texto literário para a linguagem dos quadrinhos. Alguns colaboradores da EBAL se mostravam tão preocupados em serem fiéis às obras literárias brasileiras que muitas das histórias em quadrinhos não passavam de livros ilustrados. Tanto os romances brasileiros quanto estrangeiros eram publicados conforme quatro critérios: 1) o grau de popularidade, 2) o valor literário, 3) o enredo acional e 4) a não amoralidade. Ou seja, quanto mais conhecida e valorizada a obra literária, mais vendas a história em quadrinhos poderia trazer; quanto mais ações o enredo da obra literária tivesse, mais adaptável ela poderia ser à linguagem dos quadrinhos; e não tendo qualquer referência negativa à Igreja Católica e a qualquer tipo de erotismo, a história em quadrinhos estaria menos vulnerável a censuras e às discussões (GONÇALO JUNIOR 2004).

É importante ressaltar que todos os profissionais contratados para feitura da Edição Maravilhosa (redatores, tradutores, condensadores de texto, revisores, letristas, paginadores e completadores de desenho) não tinham vínculo empregatício direto com a EBAL, o que significa que eram contratados conforme a demanda de produção e a disponibilidade de cada um, pelo fato da editora sempre buscar os melhores profissionais para suas publicações. Todavia, no que tange à tradução e à revisão do texto de chegada, pode-se dizer que tradutores, revisores e condensadores de texto trabalhavam com os mais modernos dicionários e enciclopédias para a boa produção dos quadrinhos em consonância com o código da editora EBAL.

No que tange à cronologia da séria Edição Maravilhosa, ela foi dividida em uma edição e duas reedições, além de pequenas coleções e alguns números avulsos ${ }^{4}$. A primeira edição vai de junho de 1948 a dezembro de 1968

\footnotetext{
${ }^{4}$ Informações disponíveis em <http://guiaebal.com/maravilhosa0.html>. Acesso em 31 de agosto de 2013.
} 
SILVA-ReIS, D.; LUCATELLI, B. G. - Dos Classics Illustrated à Edição Maravilhosa: Victor Hugo entre textos e paratextos (1949-1959)

com o total de 201 revistas em quadrinhos. A segunda edição, de janeiro de 1958 a novembro de 1960 com 24 revistas. E a terceira reedição, chamada de Maravilhas da Edição Maravilhosa, vai de janeiro a outubro de 1967 com apenas 10 títulos. Há ainda a Edição Maravilhosa em Cores, também chamada de Série Júlio Verne, com 12 títulos, e a série Edição Maravilhosa Mini heróis com 8 revistas. Além disso, existiam as revistas avulsas: Edição Maravilhosa Especial - Sinhá Moça, Edição Maravilhosa Extra: História dos Estados Unidos, Edição Maravilhosa $O$ tronco de Ipê e A bagaceira quadrinizada.

Por fim, cabe mencionar que a Edição Maravilhosa também foi a incentivadora de uma série de coleções da própria EBAL, mas igualmente de outras editoras que também visavam adaptar Literatura em quadrinhos como Romance em Quadrinhos, O Correio, Álbum Gigante, Manchete, Edição Monumental dentre outras.

\section{Análises Textuais: Dos Classics Illustrated à Edição Maravilhosa}

As análises comparativas entre os textos em inglês e suas respectivas traduções para o português são importantes fontes de dados que mostram os objetivos das editoras e qual a relação que tinham com seu público-alvo. Neste trabalho, a metodologia utilizada para as análises foi a seguinte: inicialmente, foi feita uma análise geral para comparar o número de páginas e quadrinhos e para identificar se as obras em inglês e em português seguiam o mesmo padrão no que se refere aos quadrinhos e, portanto, se uma era realmente a tradução da outra. Em um segundo momento, foi feita a análise detalhada, balão a balão, com o objetivo de identificar os procedimentos tradutórios utilizados pela editora Brasil-América Ltda (EBAL). 
SILVA-Reis, D.; LuCATELLI, B. G. - Dos Classics Illustrated à Edição Maravilhosa: Victor Hugo entre textos e paratextos (1949-1959)

Para a classificação dos procedimentos tradutórios, tomamos como base o modelo de Vinay e Dalbernet (1977: 46-55, apud BARBOSA 1990), segundo o qual os procedimentos técnicos da tradução podem ser classificados em duas categorias - tradução direta (empréstimo, decalque e tradução literal) e tradução oblíqua (transposição, modulação, equivalência e adaptação). Tais categorias apresentam procedimentos de primeiro grau que originam inúmeros outros. Embora este modelo já esteja um pouco defasado, para uma análise diacrônica e minuciosa do texto traduzido, consideramos que ainda é de grande valia.

Partindo dessa definição, apresentamos a seguir gráficos com o número de cada um dos processos identificados: equivalência, transposição, omissão, modulação e melhorias textuais. Vale ressaltar que outros processos também foram identificados, mas não contabilizados porque não se encaixariam, necessariamente, no modelo de análise aqui escolhido. É importante lembrar também que optamos por esse modelo porque as categorias nele definidas foram as mais frequentes.

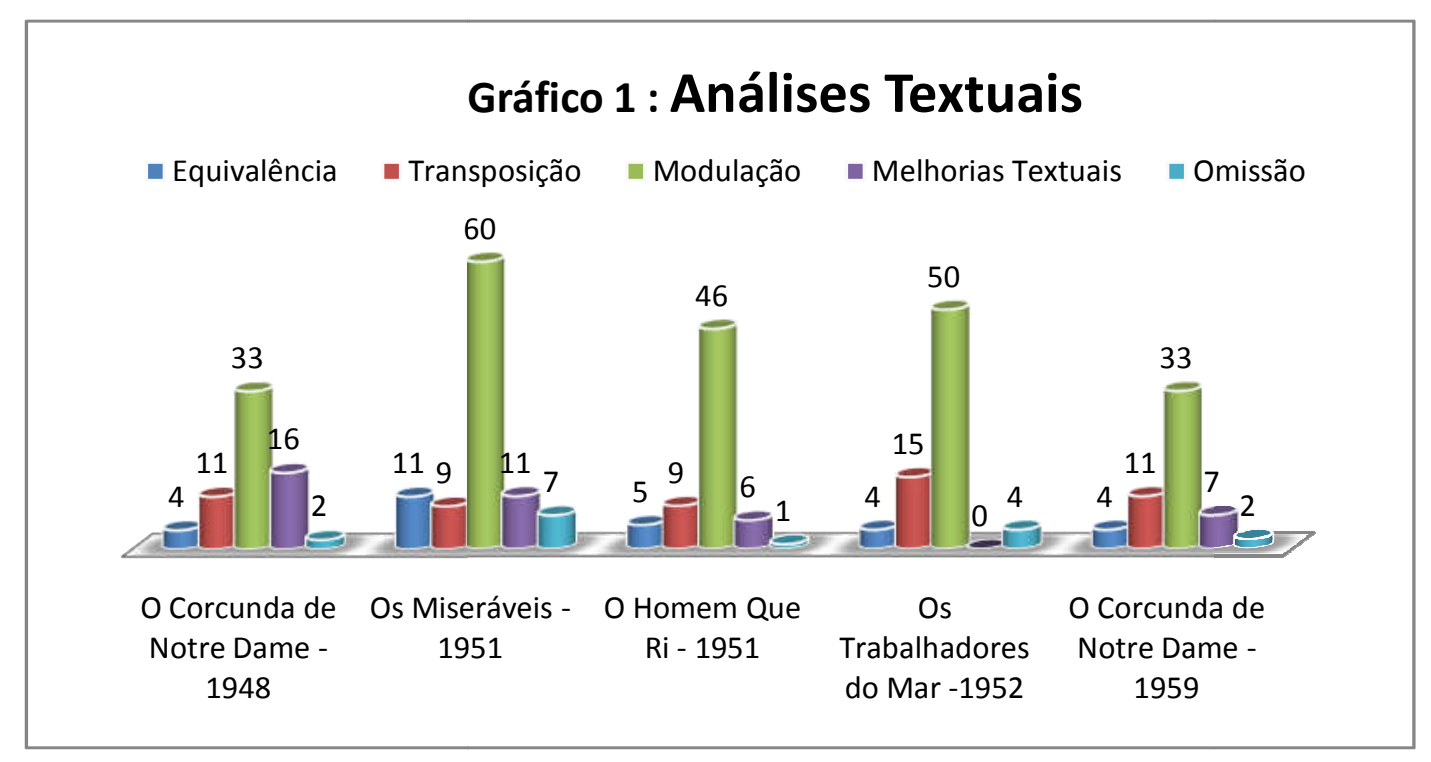


SILVA-REIS, D.; LuCATELLI, B. G. - Dos Classics Illustrated à Edição Maravilhosa: Victor Hugo entre textos e paratextos (1949-1959)

Tendo como base os dados acima, veremos, então, alguns exemplos de como esses procedimentos apareceram nas obras aqui analisadas e, para isso, começaremos pela equivalência.

Esta é uma estratégia que deve ser usada quando as duas línguas envolvidas abordam a mesma situação de formas diferentes, ou seja, por meio estilísticos e textuais variados (BARBOSA 1990).

É interessante observar que o número de ocorrências de equivalências em Os Miseráveis está bem acima da média. Isso nos mostra que nessa edição o tradutor, com alguma liberdade, buscou aproximar bastante o texto da realidade de seu leitor. Já nas outras edições, o número de ocorrências foi menor provavelmente porque os enredos em si não permitiam ou exigiam o uso de tal recurso. Tal modo de traduzir está em sintonia com os "mandamentos da tradução" da editora EBAL que privilegiava a regionalização, nacionalização ou domesticação de situações e contextos. Vejamos alguns exemplos:

\begin{tabular}{|l|l|l|}
\hline \multicolumn{2}{|l|}{ TABELA 1: EXEMPLOS DE EQUIVALÊNCIA } \\
\hline $\begin{array}{l}\text { O Corcunda de } \\
\text { Notre Dame }\end{array}$ & Shh... & Caluda... (pp. 7) \\
\cline { 2 - 3 } & It had better be good & Oxalá seja boa! (pp. 8) \\
\hline Os Miseráveis & $\begin{array}{l}\text { Work, you dogs! Or you'll get a } \\
\text { double chain around your } \\
\text { neck. (pp. 3) }\end{array}$ & $\begin{array}{l}\text { Ao trabalho! Ou quereis umas } \\
\text { boas correadas no lombo? (pp. } \\
5)\end{array}$ \\
\cline { 2 - 3 } & $\begin{array}{l}\text { A splash - then the waters roll } \\
\text { smoothly again. (pp. 21) }\end{array}$ & $\begin{array}{l}\text { Um baque, e depois a superfície } \\
\text { das águas torna a fechar-se. } \\
\text { (pp.22) }\end{array}$ \\
\hline $\begin{array}{l}\text { Ri Homem que } \\
\text { is on the record. }\end{array}$ & $\begin{array}{l}\text { Clerk! Be sure that all of this } \\
\text { iscrivão: Não deixeis de } \\
\text { registrar uma, sequer, de suas } \\
\text { palavras! (pp. 33) }\end{array}$ \\
\hline
\end{tabular}

Nos exemplos aqui apresentados, podemos notar que essa estratégia de tradução foi utilizada, principalmente, para traduzir expressões. Por exemplo: 
SILVA-ReIS, D.; LuCATELLI, B. G. - Dos Classics Illustrated à Edição Maravilhosa: Victor Hugo entre textos e paratextos (1949-1959)

Ao utilizar "Oxalá seja boa!" para expressar "It had better be good” (tradução livre: “É melhor que seja boa”!), o tradutor optou por algo para aproximar o texto de seu público-alvo, utilizando uma interjeição que não estava presente em inglês. Embora no texto original a ideia de desejo também estivesse presente, ao optar pela tradução utilizando "oxalá" (do árabe wa xallah ou in xallah, "queira Deus", "se Deus quiser”), o tradutor aproxima a linguagem da cultura na qual o leitor está inserido.

Essa preocupação com a recepção da tradução levou também ao uso da técnica da transposição, que consiste em fazer uma alteração na classe gramatical dos significantes sem que o conteúdo sofra alterações (BARBOSA 1990). Essa é uma estratégia comum no processo tradutório, sendo, algumas vezes, até necessária. Além disso, pode ser usada como um recurso estilístico que torna a linguagem mais rebuscada e esse era um dos objetivos da editora EBAL. Observemos:

\begin{tabular}{|l|l|l|}
\hline TABELA 2: EXEMPLOS DE TRANSPOSIÇÃO \\
\hline Os Miseráveis & $\begin{array}{l}\text { How silver is the moonlight } \\
- \text { like the candlesticks. (pp. } \\
7)\end{array}$ & $\begin{array}{l}\text { A lua resplandece lá fora tal } \\
\text { como a prata destes candelabros. } \\
\text { (pp. 8) }\end{array}$ \\
\hline $\begin{array}{l}\text { Os } \\
\text { Trabalhadores } \\
\text { do Mar }\end{array}$ & $\begin{array}{l}\text { Do you think he can be } \\
\text { trusted? }\end{array}$ & $\begin{array}{l}\text { Acha que se pode confiar nele? } \\
\text { (pp. 4) }\end{array}$ \\
\cline { 2 - 3 } \\
$\begin{array}{l}\text { treasury has been rifled! } \\
\text { Rantaine has disappeared } \\
\text { and is nowhere to be found! }\end{array}$ & $\begin{array}{l}\text { Trago-lhe más notícias! O cofre } \\
\text { foi arrombado e Rantaine } \\
\text { desapareceu, sem que se possa } \\
\text { encontrá-lo em parte alguma. } \\
\text { (pp. 6) }\end{array}$ \\
\hline
\end{tabular}

No exemplo "How silver is the moonlight", há um mudança de foco, pois em inglês o comentário feito fala sobre "o luar" (moonlight). Em português, entretanto, a lua passa a ser o sujeito. Assim, foi feita uma mudança de foco, mas o sentido foi mantido, como propõe a transposição. 
SILVA-REIS, D.; LuCATELLI, B. G. - Dos Classics Illustrated à Edição Maravilhosa: Victor Hugo entre textos e paratextos (1949-1959)

$\mathrm{Na}$ modulação, outra técnica tradutória observada, muda-se o foco expresso na mensagem para que ela se adapte melhor ao novo contexto no qual será inserida (BARBOSA 1990). Sua utilização nas traduções das revistas pode ter tido dois principais objetivos: o primeiro, tornar a leitura mais natural; e o segundo, que ia na linha dos objetivos da editora EBAL, era aproximá-la da utilizada na literatura clássica, embora essa não seja a função inicial do procedimento. Notamos isso nos exemplos abaixo:

TABELA 3: EXEMPLOS DE MODULAÇÃO

\begin{tabular}{|l|l|l|}
\hline Os Miseráveis & $\begin{array}{l}\text { Don't take me, please! I } \\
\text { must work! (pp. 14) }\end{array}$ & $\begin{array}{l}\text { Solte-me! Tenho de trabalhar! } \\
\text { (pp.15) }\end{array}$ \\
\hline $\begin{array}{l}\text { Os Trabalhadores } \\
\text { do Mar }\end{array}$ & $\begin{array}{l}\text { These waters are a bad } \\
\text { place in foggy weather. }\end{array}$ & $\begin{array}{l}\text { E estas águas não são nada boas } \\
\text { em tempo brumoso. (pp. 13) }\end{array}$ \\
\hline O Homem que Ri & $\begin{array}{l}\text { Don't leave me! Come } \\
\text { back! }\end{array}$ & $\begin{array}{l}\text { Não me deixeis aqui! Levai-me } \\
\text { convosco! }\end{array}$ \\
\hline
\end{tabular}

$\mathrm{Na}$ tradução de "Come back", por exemplo, por "Levai-me convosco" há uma alteração no foco, pois, em inglês, a frase pede que o personagem volte. Em português, entretanto, o pedido é para que o personagem a leve. Neste caso, é possível notar que o uso da colocação pronominal torna a estrutura da frase mais rebuscada, permitindo, então, que um dos objetivos da editora (o de não distanciar a linguagem dos quadrinhos daquela presente nas obras originais) fosse atingido.

Ainda com o intuito de aproximar obra e público, identificamos também algumas melhorias textuais que são basicamente acréscimos no texto de chegada - são frases e informações que não estão presentes no texto de partida (BARBOSA, 1990). Para a contagem destes procedimentos, consideramos apenas as melhorias textuais que apareceram em forma de legenda, tornando, assim, a compreensão dos quadrinhos mais clara. Vejamos alguns exemplos:

TradTerm, São Paulo, v. 27, Setembro/2016, pp. 247-277

www.usp.br/tradterm

http://www.revistas.usp.br/tradterm/index 
SILVA-ReIS, D.; LUCATELLI, B. G. - Dos Classics Illustrated à Edição Maravilhosa: Victor Hugo entre textos e paratextos (1949-1959)

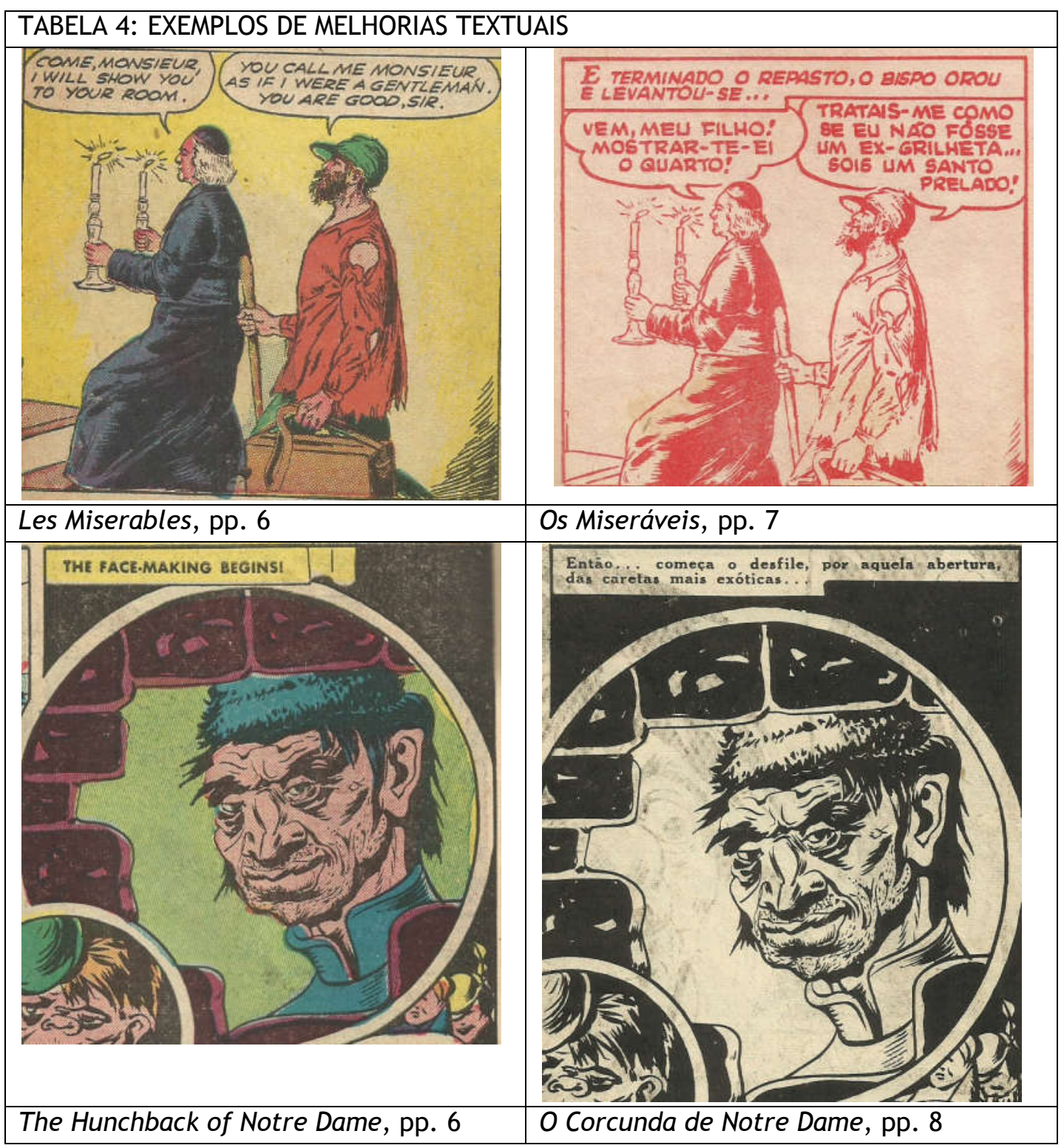

As melhorias textuais, em seu conceito mais amplo, são bastante comuns em todas as traduções analisadas. No gráfico no início desta seção, todavia, foram observadas apenas as legendas acrescentadas aos quadrinhos e que não existiam nos textos originais. É importante notar que, em 0 Corcunda de Notre Dame de 1949, esse recurso foi muito utilizado, talvez por ser ainda 
SILVA-REIS, D.; LuCATELLI, B. G. - Dos Classics Illustrated à Edição Maravilhosa: Victor Hugo entre textos e paratextos (1949-1959)

uma das primeiras publicações. Nas outras, o recurso já não é tão frequente, mas ainda assim é comum. Em Os Trabalhadores do Mar, entretanto, esse recurso não foi utilizado, mas vale ressaltar que outros recursos foram identificados e, provavelmente, tinham o mesmo objetivo de tornar a compreensão mais clara, mas isso foi feito por meio de adaptações nas próprias falas dos personagens.

Essa diferença nos leva a crer que a editora buscava, cada vez mais, manter a estrutura das histórias originais, pois, como o gráfico mostra, esse recurso passou por uma queda no número de ocorrências. Logo, o que aconteceu foi uma evolução ao longo do tempo e esses trechos que eram acrescentados foram desaparecendo. Entretanto, na versão de $O$ Corcunda de Notre Dame de 1959 (embora seja recente), isso não aconteceu, porque ela parece ser uma reedição e não uma nova tradução.

A omissão, caraterizada pelo ato de deixar de escrever algo, é feita, sobretudo, pela exclusão de palavras (BARBOSA 1990). Nesta pesquisa, consideramos também a omissão de falas completas e a retirada de páginas, embora esse último recurso não tenha sido muito frequente. Eis alguns exemplos:

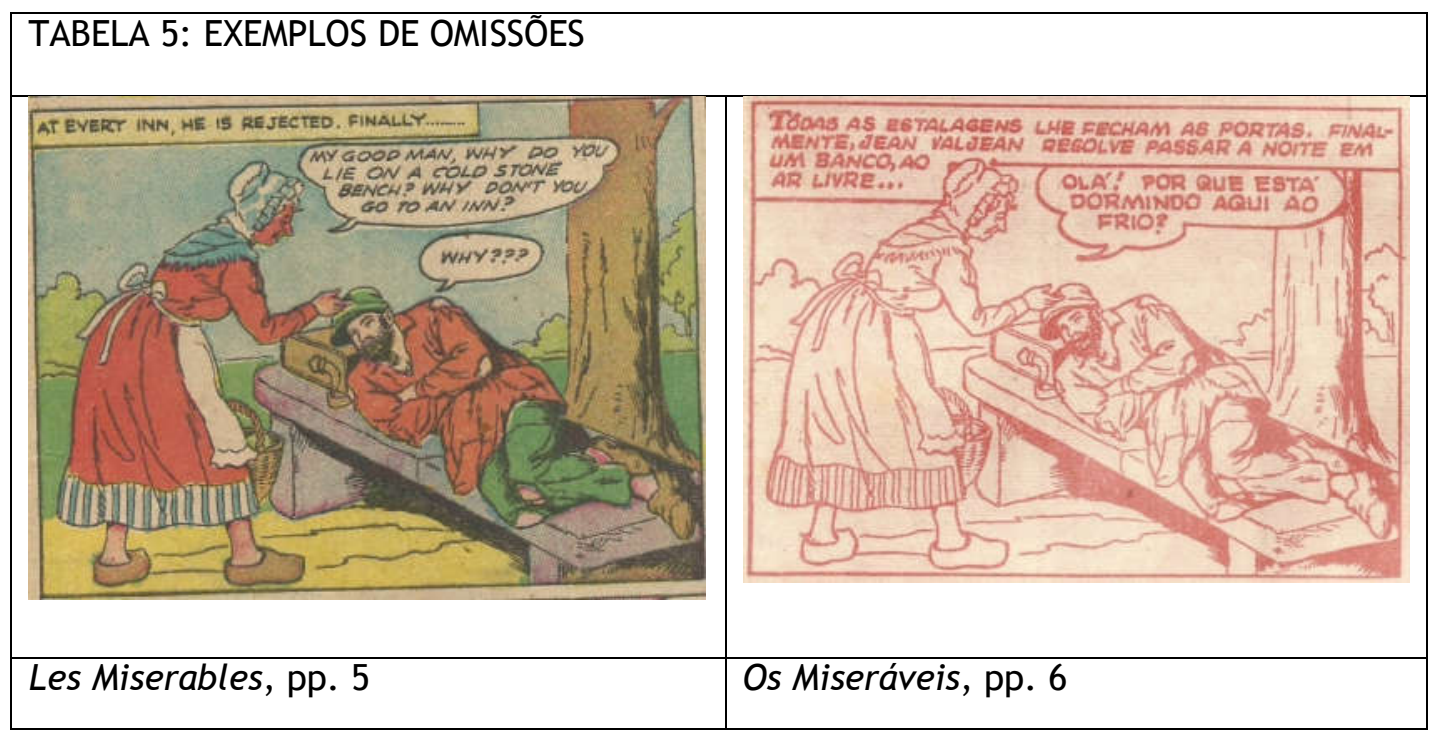

TradTerm, São Paulo, v. 27, Setembro/2016, pp. 247-277 www.usp.br/tradterm http://www.revistas.usp.br/tradterm/index 
SILVA-ReIS, D.; LuCATELLI, B. G. - Dos Classics Illustrated à Edição Maravilhosa: Victor Hugo entre textos e paratextos (1949-1959)

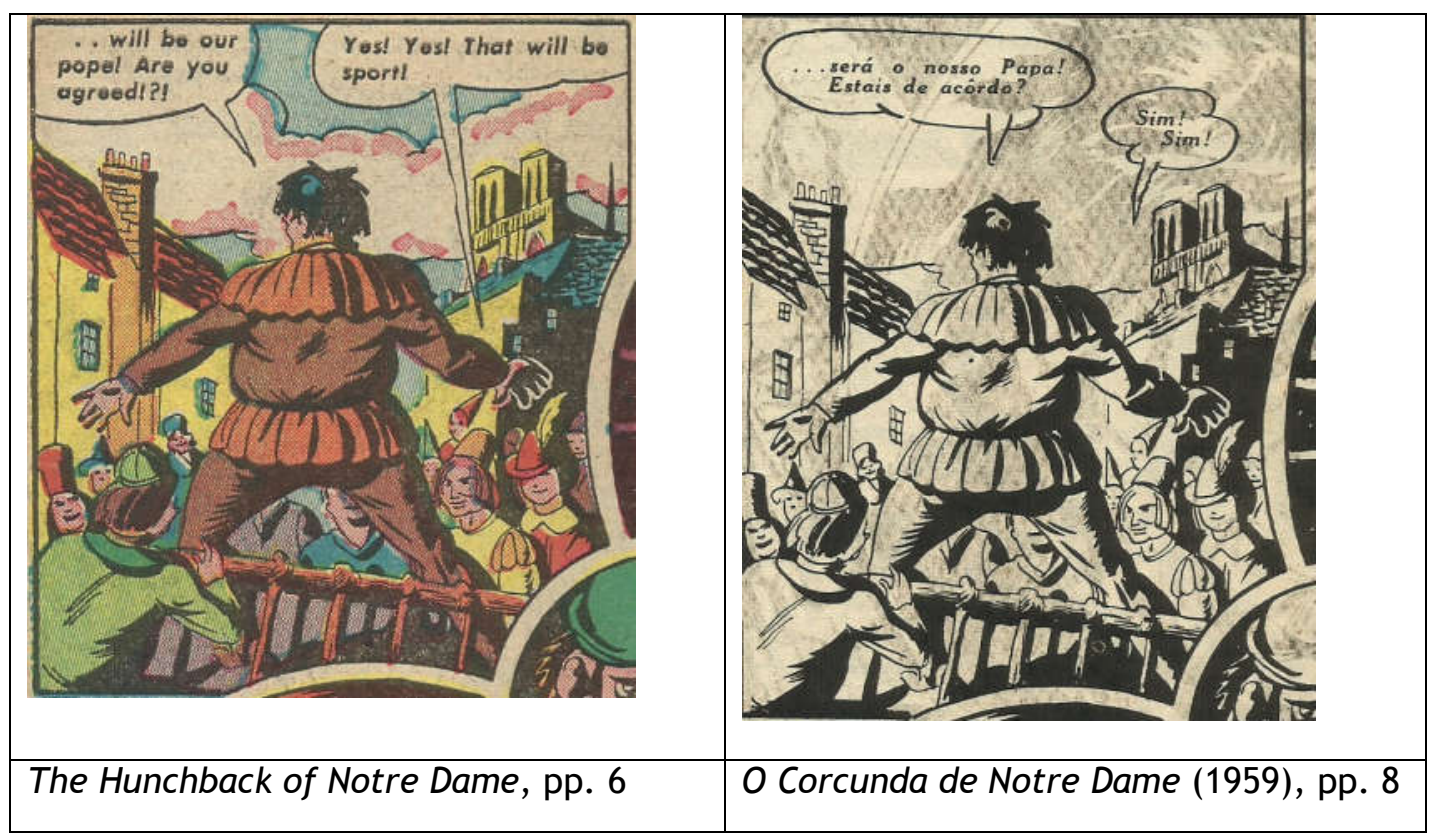

A partir de uma análise do número de ocorrências, é possível perceber que a omissão não é um recurso muito utilizado. Em Os Miseráveis, por exemplo, história na qual o recurso foi mais frequente, o número máximo de ocorrências foi 7. Isso se deve ao fato de que, muitas vezes, ao se omitir uma fala ou um quadrinho, há o risco de se perder uma informação importante e/ou relevante. Aqui, é interessante notar que em nenhum dos casos de omissão observados a compreensão foi afetada e, talvez, essa seja a razão de o procedimento ter sido utilizado, a mensagem original foi repassada ao leitor brasileiro sem que houvesse prejuízos. 
SILVA-REIS, D.; LuCATELLI, B. G. - Dos Classics Illustrated à Edição Maravilhosa: Victor Hugo entre textos e paratextos (1949-1959)

\section{Análises Paratextuais: HQs em inglês e em português}

Nas obras literárias, o paratexto desempenha um papel crucial e nas histórias em quadrinhos isso não seria diferente. Na verdade, talvez sua importância seja ainda maior, considerando a forte e fundamental relação entre texto e imagens. Nas análises a seguir, utilizamos a definição de Genette (1987), segundo a qual paratexto "é aquilo por meio de que um texto se torna livro e se propõe como tal a seus leitores, e de maneira mais geral ao público" (GeNETTE 2009: 9). Desta forma, consideramos os seguintes gêneros paratextuais: editorial, capa, quarta capa e anexos - incluímos igualmente a análise do formato, que, mesmo não sendo um paratexto, se insere como elemento importante na feitura da $\mathrm{HQ}$.

Cabe mencionar aqui o conceito de cada parte paratextual: o editorial é concebido como toda forma de comunicação estabelecida entre editora e leitor, trazendo inclusive propagandas de outros produtos da editora; já a capa é o primeiro contato do leitor com a obra e, por isso, desempenha um papel fundamental nessa comunicação, visto que traz as informações que a editora considera essenciais para o leitor e aquelas que se deseja que sejam recebidas logo em um primeiro momento. Assim como a capa, a quarta-capa, por estar na parte externa, também desempenha um papel importante no primeiro contato do leitor com a revista, apresentando informações que a editora considera interessantes e importantes de serem comunicadas, apesar de ser a última parte da publicação. Por fim, os anexos são as páginas que são acrescentadas à publicação do livro e que trazem, geralmente, informações sobre o autor ou colunas fixas presentes em todos os livros de uma editora (GENETTE 2009).

Neste trabalho, foram analisadas oito revistas (quatro em inglês e suas respectivas traduções para o português e uma segunda edição de $O$ Corcunda 
SILVA-ReIS, D.; LUCATELLI, B. G. - Dos Classics Illustrated à Edição Maravilhosa: Victor Hugo entre textos e paratextos (1949-1959)

de Notre Dame). Dentre as obras, apenas a edição brasileira de Os Miseráveis estava sem a sua capa original, mas tivemos acesso a ela pelo Guia EBAL - site do colecionador (http://guiaebal.com). Já as contracapas, uso recorrente no mercado livreiro contemporâneo, não eram tão comuns à época, e por isso, não as analisaremos aqui.

No que tange ao formato, todas as publicações em inglês apresentam as mesmas dimensões. Já em português, a versão de $O$ Concunda de Notre Dame, de 1949, é a única que apresenta um formato diferente das outras, sendo um pouco menor. Acredita-se que essa diminuição nas dimensões das revistas tenha sido uma medida para diminuir os custos da publicação que eram elevados à época no Brasil.

Com relação à capa, na primeira edição de $O$ Corcunda de Notre Dame, de 1949, o nome da coleção aparece na parte superior da página e o título, na parte inferior. Em letras muito pequenas há a seguinte observação, que aparece da mesma maneira em Os Miseráveis, logo abaixo do nome da coleção: "Romances Clássicos, Universais, Em Quadrinhos, Recomendados Para Maiores de 12 Anos de Idade".

O nome do autor da obra aparece, sem muito destaque, no lado esquerdo da página, mas, vale observar que passa por um aportuguesamento, pois aparece redigido como Vitor Hugo, sem o ' $c$ ' existente no nome original, o que não acontece nos números seguintes, nos quais o nome sempre é Victor Hugo. 
SILVA-ReIS, D.; LUCATELLI, B. G. - Dos Classics Illustrated à Edição Maravilhosa: Victor Hugo entre textos e paratextos (1949-1959)

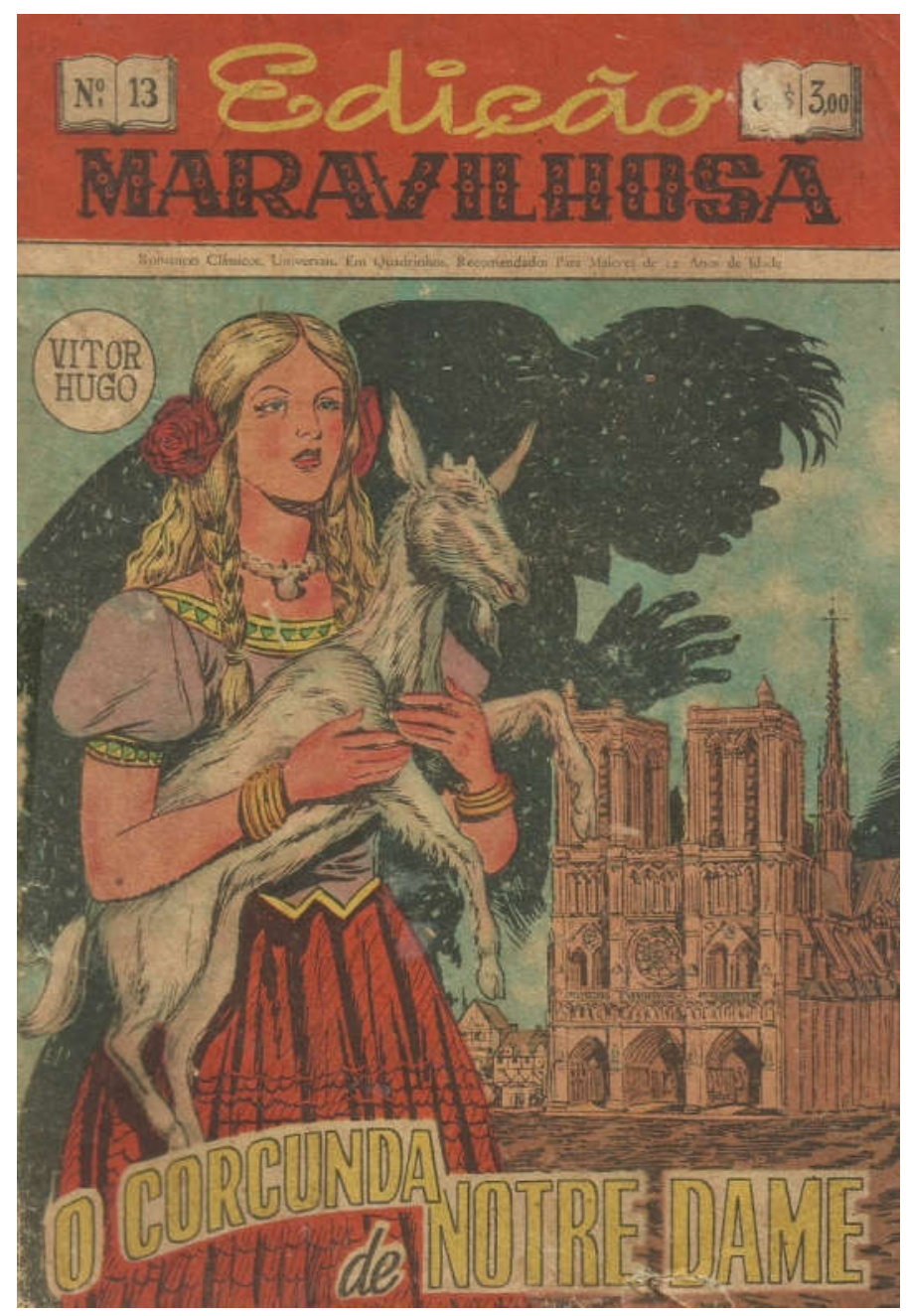

Outra informação que aparece na capa e que vale ser comentada é o preço de cada publicação. A primeira delas, O Corcunda de Notre Dame de 1949, é mais barata, custando 3,00 cruzeiros. Os Miseráveis, O Homem que Ri e Trabalhadores do Mar custavam 4,00 cruzeiros; um aumento relativamente pequeno quando comparamos todos os números e a última revista analisada, O Corcunda de Notre Dame de 1959, que custava 15,00 cruzeiros, o que pode indicar ou um alto custo da revista ou um aumento da inflação à época. É importante notar que há um intervalo temporal maior entre todas as publicações e O Corcunda de Notre Dame de 1959, o que pode justificar a variação na economia do país e, consequentemente, a elevação no preço do papel. 
SILVA-ReIS, D.; LUCATELLI, B. G. - Dos Classics Illustrated à Edição Maravilhosa: Victor Hugo entre textos e paratextos (1949-1959)

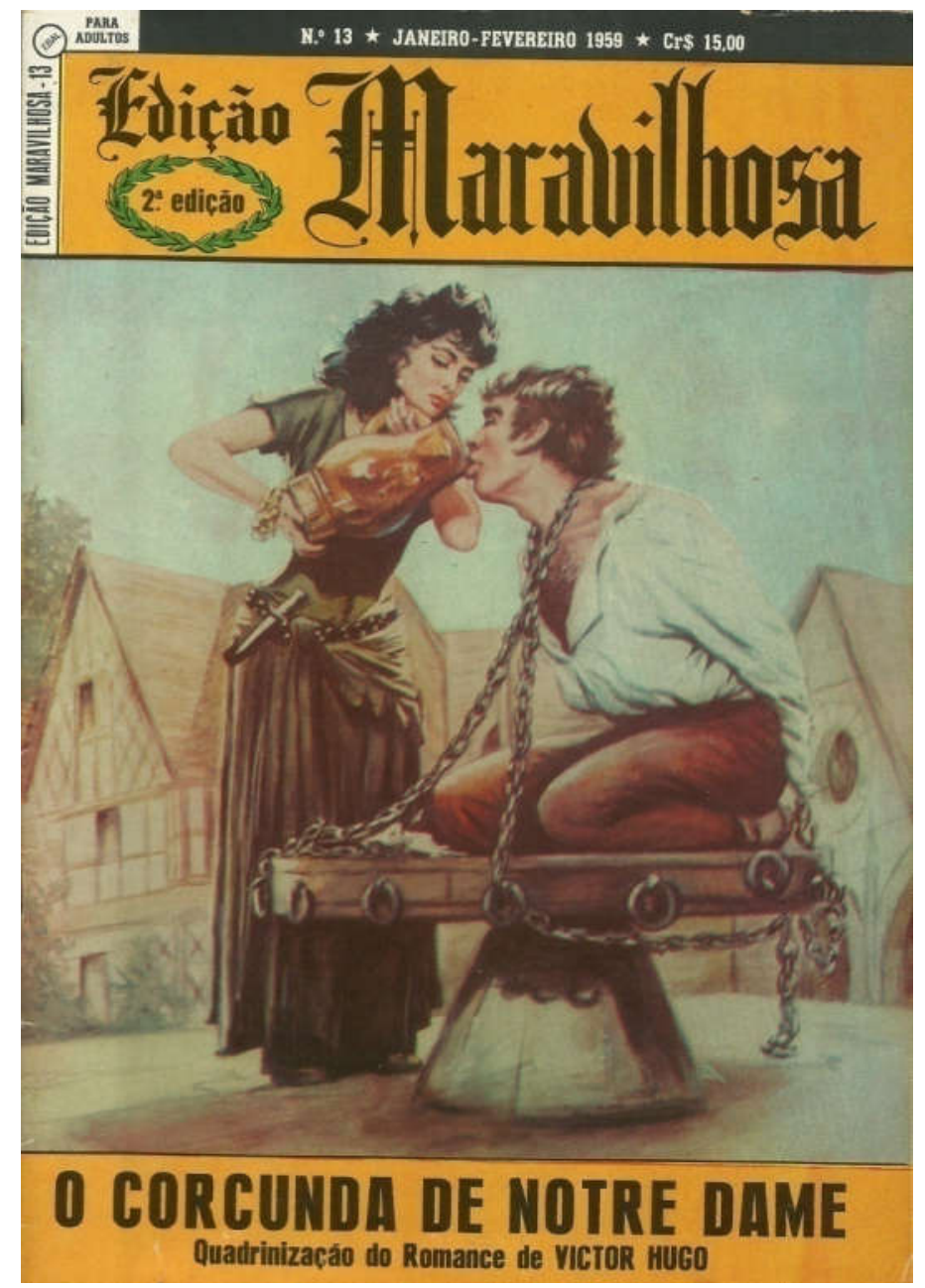

Ainda a respeito desta última publicação, vale ressaltar que, diferentemente do que acontece nas outras revistas, ela traz no canto superior esquerdo a observação de que é para adultos. Tal observação, possivelmente, está relacionada à complexidade do texto, à linguagem rebuscada e não, necessariamente, à preocupação com as críticas de que os jovens substituiriam a leitura das obras originais pela das revistas.

Nas capas em inglês, todas coloridas, a de The Hunchback of Notre Dame é aquela que mais se diferencia das outras, mas isso provavelmente se deve ao fato dela ainda ser da coleção Classic Comics. Nessa edição, vê-se o nome da coleção, seguido do slogan (Featuring stories by the world's greatest 
SILVA-ReIS, D.; LUCATELLI, B. G. - Dos Classics Illustrated à Edição Maravilhosa: Victor Hugo entre textos e paratextos (1949-1959)

authors $)^{5}$, do título e do nome do autor em fonte pequena. Não há nenhuma informação adicional, nem mesmo o preço.

Já nas outras três revistas analisadas, todas da coleção Classics Illustrated, o nome da coleção aparece no canto superior direito com o slogan já mencionado nas revistas da Classic Comics localizado ao lado. A seguir, centralizado, vê-se o título e, logo abaixo, o nome do autor. Nesses números o preço é informado, sendo que em Les Miserables o valor é de 15 cents e em The Toilers of the Sea e The Man Who Laughs, é de 10 cents, mas há a observação de que, no Canadá e outros países, o valor é de 15 cents.

Observa-se, então, que nas capas das revistas em inglês o principal objetivo era chamar a atenção do leitor com capas coloridas e bem ilustradas e com poucas informações adicionais para que ele tivesse o interesse de lêlas; independentemente da linguagem delas, o foco era o conteúdo em si. Entretanto, é importante ressaltar que a editora também tinha sua preocupação com relação às críticas que sofria, que alegavam que elas banalizavam a literatura e isso pode ser notado nas informações que serão dadas na quarta capa.

Quanto ao editorial, a edição em português buscava mostrar a relevância das publicações e como elas poderiam, inclusive, ser um ponto de partida para despertar o interesse pela leitura dos clássicos, visto que existiam muitas críticas daqueles que acreditavam que as histórias em quadrinhos não faziam jus à qualidade dos originais.

Na publicação O Corcunda de Notre Dame de 1949, o editorial apenas anuncia como serão as próximas publicações, levando em conta o sucesso de vendas dos primeiros números. 0 mesmo acontece no editorial de Os Miseráveis: as informações apresentadas são anúncios de outros números da editora. Já em Os Trabalhadores do Mar, o editor responde a perguntas dos leitores e há uma pergunta interessante na qual o leitor interroga a razão pela

\footnotetext{
5 “Apresentando histórias dos maiores autores do mundo!" (The Hunchback of Notre Dame, capa, 1929) (tradução nossa).
}

TradTerm, São Paulo, v. 27, Setembro/2016, pp. 247-277

www.usp.br/tradterm

http://www.revistas.usp.br/tradterm/index 
SILVA-ReIS, D.; LuCATELLI, B. G. - Dos Classics Illustrated à Edição Maravilhosa: Victor Hugo entre textos e paratextos (1949-1959)

qual há poucas publicações de revistas com adaptações de grandes autores brasileiros, à qual o editor responde, explicando a dificuldade de se encontrar ilustradores que queiram trabalhar com a adaptação para quadrinhos, ainda que o valor pago a eles seja elevado.

É, entretanto, na análise do editorial de $O$ Corcunda de Notre Dame de 1959 da Edição Maravilhosa que podemos notar a preocupação da editora com relação às críticas que surgiam quanto à linguagem das revistas e ao conteúdo delas. Além de trazer um anúncio sobre um álbum de figurinhas, há uma observação da editora que diz:

As Revistas em Quadrinhos de gênero recreativo que levam a marca EBAL são redigidas e recomendadas por professores, obedecendo a normas de ética jornalística e educacional. (1959)

Além disso, o editorial traz uma citação na qual um professor exalta a qualidade dos quadrinhos e diz que eles serviam como meio de motivar a leitura e a aprendizagem:

0 quadrinho, assustadoramente em moda, tanto pode ser deletério como educativo. No Brasil, mercê do idealismo da EBAL, encontrou sua canalização para o bem. Em sua humanitária alquimia, fez alimento para o espírito com o que poderia ser veneno. Rigorosamente concebido e artisticamente realizado, fez-se 0 quadrinho como instrumento de motivação e de aprendizagem visual. (Major José Hermógenes, Professor do Colégio Militar do Rio de Janeiro, 1959)

Assim, é possível notar que a editora não estava indiferente às críticas que se faziam no mundo e no Brasil e, por isso, buscava manter-se no mercado usando diversas formas: tanto por anúncios de várias outras publicações da editora quanto por meio de um canal de comunicação com o leitor, pelo qual respondia a perguntas e buscava se posicionar e expor seus objetivos. 
SILVA-ReIS, D.; LUCATELLI, B. G. - Dos Classics Illustrated à Edição Maravilhosa: Victor Hugo entre textos e paratextos (1949-1959)

Já o editorial em inglês tem variações. A partir da comparação entre as 4 revistas em inglês, observa-se que, dentre elas, The Hunchback of Notre Dame apresenta um formato do editorial diferente. Nela, esse paratexto é composto de propaganda de livros publicados pela editora e também de anúncios de outros números da Classic Comics. Aqui, é interessante notar que sempre que a coleção Classic Comics é apresentada, os autores que são adaptados são exaltados. Nesse editorial, por exemplo, aparece a seguinte frase: "Classic Comics give you the world's greatest authors"." Em contrapartida, o editorial de Les Miserables, agora já com a publicação com o nome de Classics Illustrated, traz apenas propagandas de outros produtos da editora, sem que haja aspectos que chamem atenção para a linguagem das obras ou para os autores que serão adaptados. Essas informações só aparecerão na quarta capa.

The Man Who Laughs e The Toilers of the Sea, também Classics Illustrated, apresentam um editorial que segue um mesmo formato. Nesse, há uma breve coluna contando histórias sobre situações inusitadas e engraçadas e também um curto anúncio de outro número da publicação. Neste anúncio sempre se destaca que a leitura será memorável e prazerosa. Além disso, há propagandas de outros produtos da editora, mas, nelas, o foco está nos valores e nas formas como os leitores podem adquirir tais produtos.

A partir da análise desses editoriais, pode-se notar que, embora a editora tivesse uma preocupação em citar os autores explorados nas histórias em quadrinhos, isso só aparecerá em outras partes do paratexto, pois, no editorial, a principal ideia era promover outras obras e despertar o interesse do leitor para os produtos da editora.

Em relação aos anexos, nas publicações em português, eles aparecem apenas em dois números ( $O$ Homem que Ri e Os Trabalhadores do Mar) e trazem uma breve biografia de Victor Hugo, traduzida do inglês. Já nas

\footnotetext{
6 “A Classic Comics traz para você obras de grandes autores do mundo" (tradução nossa).
} 
SILVA-ReIS, D.; LUCATELLI, B. G. - Dos Classics Illustrated à Edição Maravilhosa: Victor Hugo entre textos e paratextos (1949-1959)

revistinhas em inglês, os anexos são informações adicionais acrescentadas pela editora com os mais variados objetivos.

Todos os números trazem uma breve (e com informações diferentes a cada edição) biografia de Victor Hugo. Além disso, todas as revistas trazem outras histórias que, algumas vezes, se relacionam ao enredo da história em quadrinhos. Por exemplo: as edições de The Man Who Laughs e The Toilers of the Sea trazem três colunas fixas: Dog Heroes, Famous Operas e Pioneers of Science. Dog Heroes é a coluna que sempre traz uma história diferente com um acontecimento interessante que envolva cachorros. Já Famous Operas é a coluna em que algumas óperas são contadas de uma maneira breve. E Pioneers of Science, a coluna que sempre conta sobre alguma invenção ou descoberta importante e relevante para a ciência.

No que se refere aos anexos de Les Miserables, eles não seguem o mesmo padrão de The Man Who Laughs e The Toilers of the Sea, e trazem três textos relacionados à Revolução Francesa e à liberdade (temas ligados ao enredo da história): uma parte da Declaração dos Direitos, a Marseillaise e a história da Estátua da Liberdade, que foi um presente da França para os Estados Unidos.

Estabelecer uma relação entre a história das revistas e o que é apresentado nos anexos é algo que acontece também em The Hunchback of Notre Dame que, além de trazer a breve história de Sergeant Schiller Cohen, traz o poema "Os Sinos" de Edgar Allan Poe.

É possível notar, então, que inicialmente os anexos das revistas em inglês tinham o intuito de apresentar mais informações, mas sempre relacionadas ao enredo principal. Todavia, isso se modifica e os anexos passam a trazer informações variadas, provavelmente porque a editora começa a buscar maneiras variadas de trazer diversão e informação, sendo, assim, educativa também ao invés de puro entretenimento, ação que se refletia nos poucos anexos presentes das revistinhas em português. 
SILVA-ReIS, D.; LUCATELLI, B. G. - Dos Classics Illustrated à Edição Maravilhosa: Victor Hugo entre textos e paratextos (1949-1959)

No que concerne à quarta capa, na primeira edição de $O$ Corcunda de Notre Dame (1949) são mostrados outros números da Edição Maravilhosa e algumas formas para adquiri-los. Já na edição de $O$ Homem que $R i$, diferentemente de todos os outros, há propaganda de instrumentos musicais. Tal informação possibilita a hipótese de que a editora fazia anúncios de outros produtos externos por questões financeiras, com o intuito de baratear o custo das publicações. É importante notar, entretanto, que no interior da revista, com os anexos, há uma página que anuncia outra publicação da editora e ressalta a linguagem utilizada. Esse anúncio é exatamente o mesmo presente na quarta capa de Os Trabalhadores do Mar. Esta, por sua vez, traz informações relevantes relacionadas à preocupação da editora em se mostrar uma fonte de acesso à linguagem rebuscada. Isso pode ser observado no anúncio de uma publicação de um almanaque da própria editora, no qual se dá destaque à qualidade dos textos: "Uma joia da Língua Portuguesa", "O Verdadeiro Almanaque do Idioma de Camões e Rui Barbosa!".

A preocupação com o objetivo de ser um meio não só de diversão, mas também de instrução, também está presente na quarta capa da edição de 1959 de O Corcunda de Notre Dame, na qual se anuncia a publicação de biografias em quadrinhos e, para isso, se destacam as seguintes palavras, ao lado de uma foto da capa do primeiro número: "Instrutiva, educativa, emocionante e cultural".

A partir dessas análises, é possível notar que, com o passar do tempo, a editora buscou mostrar ao público o quanto apresentava uma linguagem rebuscada e, por isso, era também um meio de instrução para seus leitores.

No que diz respeito ao paratexto quarta capa nas revistas em inglês, a única que apresenta informações diferentes na quarta capa é The Hunchback of Notre Dame, que traz anúncios de boxes com vários clássicos da coleção, exaltando os autores dos originais e o quanto a leitura pode ser agradável. Isso pode ser observado na seguinte nota: "Every issue a complete adaptation 
SILVA-ReIS, D.; LuCATELLI, B. G. - Dos Classics Illustrated à Edição Maravilhosa: Victor Hugo entre textos e paratextos (1949-1959)

of a great story by the world's imortal authors. Each Page chock full of exciting-chilling-thrilling adventure ${ }^{7}$ ".

O conteúdo da nota acima também aparece de outras maneiras na quarta capa das outras três revistinhas que, por sua vez, seguem um padrão. Em todas elas, há uma lista com outros números da publicação e um cupom a ser preenchido para que tais números possam ser adquiridos via correio.

Embora todas exaltem os grandes autores que são adaptados e o quanto a leitura é uma boa forma de entretenimento, a edição de Les Miserables tem um pequeno texto logo na parte superior que diz que as revistas da série Classics Illustrated são também informativas: “They're exciting, informative, thrilling, educational. Each title contains a complete adaptation - plus factual, enjoyable and educational featurettes ${ }^{8}$.

\footnotetext{
7 "Toda edição é um adaptação completa de um grande clássico de autores imortais do mundo todo. Cada página é repleta de emoção, diversão e aventura" (tradução nossa).

8 "Elas são excitantes, informativas, emocionantes e educativas. Cada título contém uma adaptação completa, além de características factuais, interessantes e educativas" (tradução nossa).
} 
SILVA-ReIS, D.; LuCATELLI, B. G. - Dos Classics Illustrated à Edição Maravilhosa: Victor Hugo entre textos e paratextos (1949-1959)

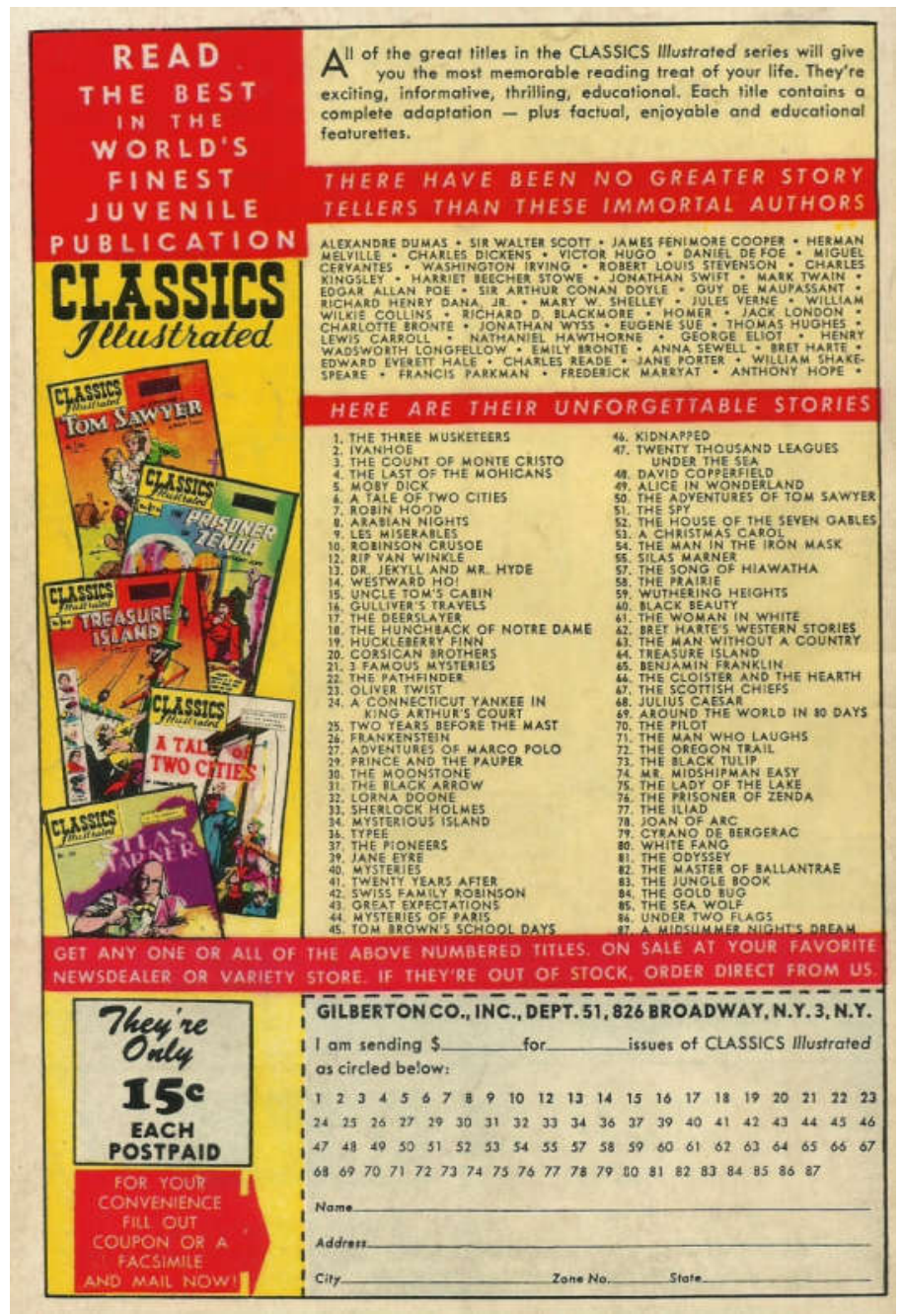

Com essa observação, é possível notar que a editora buscava mostrar ao leitor que os conteúdos de suas publicações, ainda que fossem adaptações, não alteravam o enredo das obras originais. Além disso, a leitura dos quadrinhos era, principalmente, uma maneira de diversão e entretenimento, mas sem deixar de ser informativa.

Ao observamos os paratextos das edições em inglês e em português, podemos perceber muitas informações sobre as editoras e seus objetivos nos mercados editoriais nos quais estavam inseridas.

É interessante notar que, ainda com o nome de Classic Comics, logo que foi lançada, a coleção em inglês foi bastante criticada por trazer em suas 
SILVA-ReIS, D.; LUCATELLI, B. G. - Dos Classics Illustrated à Edição Maravilhosa: Victor Hugo entre textos e paratextos (1949-1959)

páginas adaptações de grandes clássicos e isso foi considerado por muitos uma forma de banalizar e trivializar a literatura. Assim, a editora buscava sempre exaltar os autores e, nos anexos, trazer informações que pudessem fornecer conhecimento ao leitor, fossem essas informações relacionadas ao enredo da história ou não. Dessa forma, a editora se tornava recreativa e informativa.

Nas edições em português, entretanto, a editora mostrou-se muito mais preocupada em ser considerada literatura de qualidade. Essa preocupação pode ser percebida pelos editoriais e pelas informações apresentadas na quarta capa, as quais sempre traziam frases ou palavras que remetessem à linguagem rebuscada e, portanto, considerada clássica.

Acredita-se que essa preocupação fosse maior e mais perceptível nas edições em português, porque a publicação em inglês, desde a sua criação, tinha como ideal entreter e, por isso, apesar das críticas, priorizava vender essa ideia. Na tradução, todavia, essa não era a prioridade, pois a editora tinha ideais diferentes. A editora EBAL primava pela fama de fonte de boa literatura e, então, buscava deixar isso claro nos editoriais, anúncios, capa e quarta capa.

Outro aspecto relevante é o preço das revistas, talvez muito mais alto no Brasil. Essa diferença pode estar relacionada ao custo de produção (papel, impressão, tradução e distribuição) e a fatores da economia mundial que tornavam a taxa de câmbio elevada.

É importante notar, portanto, que, apesar de ser uma tradução que tinha o texto e as ilustrações dos originais em inglês como pontos de partida, a editora EBAL não deixou de se posicionar de uma maneira diferente para manter-se considerada fonte de 'boa literatura'. Esse objetivo pode ser percebido tanto por meio de adaptações linguísticas presentes na tradução do texto em si quanto por meio dos anúncios e dos editorais presentes nas edições. 
SILVA-ReIS, D.; LUCATELLI, B. G. - Dos Classics Illustrated à Edição Maravilhosa: Victor Hugo entre textos e paratextos (1949-1959)

\section{Considerações Finais}

A partir das análises dos elementos das revistas originais e das revistas traduzidas, paratextos e textos, podemos notar que houve, em todas as edições em português, uma preocupação por parte da editora EBAL de se mostrar uma fonte de literatura de qualidade. Para isso, a editora lançava mão de recursos publicitários em seus anúncios e também de recursos tradutórios que aproximavam o texto dos quadrinhos da literatura clássica.

Considerando os procedimentos técnicos identificados que foram utilizados pelos tradutores e as diferenças entre as versões em inglês e em português, acredita-se que os tradutores eram pessoas que tinham bom conhecimento da língua inglesa. Isso porque os procedimentos adotados não interferiram na compreensão da história e, muitas vezes, tornaram-na mais clara e os quadrinhos mais explicativos, até mesmo mais didáticos. Ainda levando em consideração o objetivo da editora no Brasil de apresentar uma linguagem mais rebuscada, é possível também que houvesse, além do tradutor, um melhorador de textos. Este seria o responsável por fazer as alterações nas traduções de forma que a linguagem se aproximasse mais daquela dos textos clássicos.

Dessa forma, observa-se que, apesar de haver uma preocupação em manter o sentido da história, muitas vezes a linguagem presente nos quadrinhos em português se distancia bastante da linguagem falada, o que não é comum nas revistas originais, nas quais traços de oralidade podem ser notados. É nesse aspecto, portanto, que as edições em inglês e português mais se distanciam, pois, ainda que as coleções seguissem o mesmo modelo, os objetivos das editoras com relação ao seu público-alvo e ao mercado editorial eram diferentes e isso fica evidente tanto na forma como utilizam os paratextos quanto na linguagem utilizada para contar as mesmas histórias adaptadas de grandes clássicos. 
SILVA-ReIS, D.; LUCATELLI, B. G. - Dos Classics Illustrated à Edição Maravilhosa: Victor Hugo entre textos e paratextos (1949-1959)

Possivelmente, essa preocupação com a formalidade da linguagem das revistas brasileiras se relacione com a literatura feita no Brasil no período. A Geração de 45, talvez, seja a grande influência para as revistas em quadrinhos, pois as primeiras publicações já apresentavam traços daquilo que viria a ser consolidado: a formalidade que os próprios escritores brasileiros buscavam mostrar em suas obras literárias. Dessa forma, a importância e a possibilidade de se estabelecer uma relação entre o movimento literário nacional e as traduções se deve, principalmente, ao fato da editora se preocupar em vender as revistas também como literatura. Dessa maneira, para se aproximar da literatura clássica (traduzida ou não) da época era importante seguir o estilo dos autores ditos "clássicos" e exemplares quanto ao estilo e à língua escrita equiparando, assim, história em quadrinhos a romances do cânone internacional, como é o caso do escritor Victor Hugo aqui analisado.

\section{Referências Bibliográficas}

Barbosa, H. G. Procedimentos técnicos da tradução: uma nova proposta. São Paulo: Pontes, 1990.

JONES, W. B. Jr. Classics Illustrated: A Cultural History, $2^{\mathrm{a}}$ ed. Mc Farland, 2011.

JUNIOR, G. A guerra dos gibis: a formação do mercado editorial brasileiro e a censura aos quadrinhos, 1933-64. São Paulo: Companhia das Letras, 2004.

GenetTe, G. Paratextos Editoriais. Tradução Alvaro Faleiros. São Paulo: Ateliê Editorial, 2009.

CIRNE, M; et al. Literatura em quadrinhos no Brasil: Acervo da Biblioteca Nacional. Rio de Janeiro: Nova Fronteira/ Fundação Biblioteca Nacional, 2002. VergueIRo, W. Desenvolvimento e tendência do mercado e quadrinhos no Brasil. In: ; SANTOS, R. A história em quadrinhos no Brasil. São Paulo: Laços, 2011. 
SILVA-ReIS, D.; LuCATELLI, B. G. - Dos Classics Illustrated à Edição Maravilhosa: Victor Hugo entre textos e paratextos (1949-1959)

GoIDA; KLEINERT, A. Enciclopédia dos quadrinhos. Rio Grande do Sul: L\&PM Editores, 2011.

\section{HQs Analisados}

Corpus em português

O corcunda de Notre Dame - Edição maravilhosa - n 13 - 1949

Os miseráveis - Edição maravilhosa - $\mathrm{n}^{0} 33$ - 1951

O homem que ri - Edição maravilhosa - n 39 - 1951

Trabalhadores do mar - Edição maravilhosa - n 43 - 1952

O corcunda de Notre Dame - Edição maravilhosa - nº 13 - 1959

Corpus em inglês

Les Miserables - Classics llustrated - $n^{\circ} 9-1943$

The Hunchback of Notre Dame- Classic Comics - $n^{\circ} 18$-1946

The Toilers of the Sea-Classics Ilustrated - ${ }^{0} 56-1949$

The Man Who Laughs- Classics Ilustrated - $n^{\circ} 71$ - 1950 